\title{
The Development of Audio-Visual Learning Media based on Kenduri Laot Tradition for Students at SMA Plus Athiyah Banda Aceh City to Increase Character Values
}

\author{
${ }^{1}$ Nina Suryana, ${ }^{2}$ Sufandi Iswanto, ${ }^{3}$ Heri Fajri \\ ${ }^{1,3}$ Department of History Education, Jabal Ghafur University, Gle Gapui Street, \\ Peutoe, Sigli, Kabupaten Pidie Sigli, Aceh, Indonesia \\ ${ }^{2}$ Department of History Education, Syiah Kuala University, Teuku Nyak Arief \\ Street No. 441, Kopelma Darussalam, Kec. Syiah Kuala, Banda Aceh, Indonesia \\ Email: ${ }^{1}$ ninasuryana@unigha.ac.id, ${ }^{2}$ sufandiiswanto@unsyiah.ac.id, \\ ${ }^{3}$ herifajri@unigha.ac.id
}

\begin{tabular}{l}
\hline Available Online: \\
\hline http://www.jurnal.unublitar.ac.id/ \\
index.php/briliant
\end{tabular}

History of the Article:

Received on November 2020

Accepted on March 2021

Published on May 2021

Pages 261-276

\begin{tabular}{l}
\hline Keywords: \\
\hline Development; Media; Kenduri \\
Laot tradition; Character Values \\
\hline DOI: \\
\hline http://dx.doi.org/10.28926/briliant \\
.v3i4.601
\end{tabular}

\begin{abstract}
The planting of character values in schools based on local wisdom is one of the breakthroughs that can be done by the teacher. One of them with the values the Kenduri Laot tradition that can be developed in the form of learning media. This study aims to develop a lesson plan design in the form of audio visual media-based of the Kenduri Laot tradition to improve the character of students in SMA Plus Athiyah Banda Aceh. The method used is research and development. This method refers to the model of Gall and Borg with the simplification of the stages from ten to three, namely the formulation of the problem, the designer of the development, and the effectiveness of or reflection. Based on the results of the study found a problem that during this time the planting of character values-based of the Kenduri Laot tradition is still not maximized. At this stage of development, carried out the preparation of the synopsis to test the expert audio-visual media. The
\end{abstract} results of the effectiveness of the t-Test shows that the significance value in the experimental group of $0.000<0.05$ and in the control group amounted to $0.025>0.05$, meaning that there is an increase of the characters in the experimental group.

\section{INTRODUCTION}

Education is an effort to help students develop their abilities. Besides, education is also an effort for preparing students to have competencies that can contribute to society and the life of the nation and state (Azis, Haikal, \& Iswanto, 2018: 287). Education is also a human effort to develop innate or existing potentials in a person both physically and spiritually, in accordance with the values that exist in society and local culture (Fuad, 2005: 2). Technically, education is also character education carried out through an institution, namely an educational institution, by transforming the legacy of knowledge, values and skills from generation to generation (Siswoyo, 2014: 20). Thus, it can be said that education is an effort made to develop the potential of a person both physically and spiritually, all of which should be in accordance with the existing values in society. 
In today's modern era, the problem of education in Indonesia is increasingly complex and has become the concern of all stakeholders, especially the problem of character degradation. This problem has become the most prominent issue which is often associated with the weakness of our education. According to Kaslim in (Zuriah, Syaifuddin, \& Taufik, 2017: 10), the culture and character of our nation at this time has become a spotlight from the community. The spotlight is not only on one aspect but on various aspects of life which are widely expressed in printed media, interviews, dialogues, and speech titles in various media that we can see every day. Problems that arise in our society such as corruption, violence, consumptive lifestyles, crisis of exemplary, thuggery, and others have always been discussed in the mass media. Ingsih, Ratnawati, Nuryanto, \& Astuti (2018: 2) added that in our adolescents, the problem that often arises is that our adolescents tend to be ignorant, do not care, lack courtesy, and many moral and character problems. According to Samani \& Hariyanto (2011: 1) the root of all such evil and bad actions lies in the character or character education itself.

In response to these problems, the Indonesian government has various efforts through the Ministry of Education and Culture. According to Joenaidy (2018: 160), one of which is the strengthening of character education (In Bahasa known as PPK) program which is carried out to instill five main values, including religious, nationalist, integrity, independence, and cooperation. Through this PKK, teachers are also given broad obligations in order to implement these five main values. Dinangsit (2014: 536) stated that it has also been stated in the 2013 curriculum which emphasizes character which is part of the humanistic approach. Based on Didik Suhardi in (Mustari, 2014: V), all of this is in accordance with the vision of Indonesia's National Development, namely "to realize Indonesia as a nation that is tough, competitive, noble character, moral, virtuous, tolerant, cooperative, patriotic, dynamic development, and science and technology-oriented (which is imbued with faith and piety in God Almighty based on Pancasila) are included in the National Long-Term Development Strategic Plan 2005-2025: RI Law Number 17 of 2007).

Previously, it was mentioned that in instilling character values in schools, teachers are given the obligation and authority by the government to instill these character values in various ways. Teachers as educators are expected to be able to innovate by making various breakthroughs in instilling character values both in direct learning and in the school environment. One of the breakthroughs that teachers can do is to teach teaching materials based on local wisdom. According to Ferdianto \& Setiyani (2018: 40), local wisdom itself is a guide in life and becomes the character of the Indonesian nation. By teaching local wisdom, it is the same as teaching students to be able to instill something concrete that they face and cultural development that is dynamic.

Local wisdom is basically a local culture that exists throughout Indonesia. It contains noble values which in general also contain religious, ethical, moral, and other values. It can be in the form of a tradition that has become a habit with the aim of creating positive harmony and order. One example is the Kenduri Laot tradition in Acehnese community. The Kenduri Laot tradition itself is one of the local traditions that has grown and developed in Acehnese community for hundreds of years. This tradition, which is closely related to fishermen and the 
sea, is one form or example of local wisdom that contains values such as religion, mutual cooperation, virtue, and so on.

Starting from that, the author made observations at one of the schools in Banda Aceh, namely SMA Plus Athiyah to find out how far the character has been instilled. In this case, the character has basically been taught by the teacher. However, the results of interviews with teachers and students show that character instilling through local wisdom-based teaching materials such as the Kenduri Laot tradition has never been done. Even though the teacher has used various supporting materials in learning such as media, modules, models, and others. It's just that in its development, the teacher has never included Kenduri Laot tradition as material that supports students to maintain local culture and recognize the values.

Starting from the above issue, there are some studies that have been done by some researchers related the tradition of the Kenduri Laut. The first study of Manan (2016) with the title The Ritual of Khanduri Laot in Lowland Aceh: An Ethnographic Study in South, South West and West Aceh. The research aims to describe and analyze critically about the ritual Kenduri Laot in some coastal areas of Aceh. Methods this research is a field research that is done by observation and interview. The results of this study focused on the fishermen who make offerings and the recitation of the verses of the Qur'an. The purpose of offerings is made to keep the fish in the pond, beach, ocean, the surface of the sea, the waves and the sea in. According to the fishermen, the exchange of the cosmos needs to be done as a protection for them from the disturbance of the sea and the fish will come closer to the edge. Then here could be said Kenduri Laot very terms of the valuethe value. The second study of Apriana (2016) with the title of the Local Wisdom of the People of Aceh in Marine Conservation, this study aims to identify the local wisdom of the people of Aceh in marine conservation. The approach used is a qualitative study using the method of direct observation and in-depth interviews on the informants in the Village Lampulo Kecamatan Kuta Alam Banda Aceh. The results showed that one of the local wisdom contained in the community Lampulo is the presence of marine conservation that includes a positive habit, the habit of negative, the rules of which may be done, the rules that should not be done, and custom sanction. In this study also discussed about the Panglima Laot and Kenduri Laut. In this case can see that the Kenduri Laot also part of the local wisdom of the community Lampulo in particular and the coast of Aceh general.

Research the third of Kurniasari \& Nurlaili (2012)with the title Function of the Sea in Maintaining the Harmonization of Life of Indigenous Peoples Lambadalhok Aceh Besar. This study aims to analyze the function of the harmonization of the life of the Village community Lambadalhok Village, Aceh Besar. The method used is a qualitative method and descriptive analysis. In this study, there is a harmonization of the relationship between man and God and nature, and also touched upon the issue of Kenduri Laot that has a value of spiritual power that serves as a religious, social, and economic.

The third of these studies suggests that the Kenduri Laot tradition of the condition will be noble values. If it is associated with the values of the characters that are on the Kurikulum 2013 then the values of the Feast of the Sea is relevant to the character values that are expected. However, the third research terseubut only limited research descriptive analysis has not yet reached the stage of design 
lesson plan at school. Therefore, this research is designed in the form of audio visual media with the use of this type of research and development. Then the previous research ca $n$ be said as a state of art which can be used as support and referral in this study.

This study aims to explore: 1) how the use of media and character values in SMA Plus Athiyah, 2) develop audio-visual learning media based on local cultural materials, namely Kenduri Laot tradition, and 3) test the effectiveness of instructional media in increasing the character values of students. By developing historical learning media based on Kenduri Laot tradition, it is hoped that it can stimulate and motivate teachers to continue to innovate various learning media. In addition, this research is also expected to be a way of introducing local culture and knowing the extent of the values contained in the Kenduri Laot tradition affect the character of students.

\section{METHOD}

This study is research and development based on Gall, M. D., Gall, J. P., \& Borg (2003). This research is usually carried out systematically and has several objectives, including finding out, formulating, refining, developing, producing, and testing the effectiveness of the product being developed (Suryana, Fajri, \& Iswanto, 2020: 114). The research and development that based on this model (Gall, M. D., Gall, J. P., \& Borg (2003) is divided into ten steps, namely: (1) Finding the goals and identities, (2) Conducting instructional analysis, (3) Analyzing students and their context, (4) Formulating product performance objectives, (5) Developing assessment instruments, (6) Developing instructional designs, (7) Developing and selecting products, (8) Designing and evaluating formative instructions, (9) Revising instructional, and (10) Designing and conducting summative evaluations.

Of the ten steps, an adjusted simplification is carried out based on the model from Yusuf (2017: 21) namely carrying out problem management (research objectives) clearly, conducting preliminary studies systematically, designing development research, carrying out research adapted to the established design, evaluating the process and reflection, and compiling research reports. Putra (2013: 68) adds that at the stage of designing and conducting formal evaluations, researchers will usually involve experts with diverse backgrounds. Therefore $\mathrm{R} \&$ $\mathrm{D}$ research is also referred to as research and multi-work. At the summative evaluation stage, an extensive trial was carried out involving two classes, namely the control class and the experimental class using quantitative analysis. This was done to determine the main purpose of the media being developed to find out how far the audio-visual media based on the Kenduri Laot tradition can increase students' character.

This research was conducted at SMA Plus Athiyah which is located at Jalan Tgk. Daud Beureueh Lorong Metro Gampong Beurawe, Kuta Alam District, Banda Aceh City, Aceh Province. The population in this study were all students of class XI and the samples were students of class XI A as the control class and students of class XI B as the experimental class. Data collection techniques in this study were carried out in various ways, including: observation, interviews, document analysis, and questionnaires. While the data analysis technique was carried out in stages, including: data reduction and formulas that were adjusted to 
the experimental research method, namely Quasi Experimental Design which started from the instrument test (character questionnaire). It included reliability testing, and validity testing. Then, it continued with the test in the control and experimental class with the stages: normality test, homogeneity test, and t-test.

\section{RESULTS AND DISCUSSION}

The findings show that the use of instructional media at SMA Plus Athiyah has been maximal. This is due to professional human resources and is supported by adequate school facilities. However, several problems were found related to the lack of character values. So far, teachers are considered to have not been maximal in instilling character values. Even though Aceh as a province that is rich in culture and based on Islamic law, all aspects such as character, should be in accordance with Aceh's culture which is based on Islam. Almost all Acehnese culture has values and if they are linked, these values are in accordance with the demands of our education to instill 18 character values contained in the 2013 curriculum.

One example of Acehnese culture that is based on Islam and which can still be enjoyed today is Kenduri Laot tradition. The tradition that has been carried out from generation to generation is a tradition that is carried out as a thanksgiving for the coastal community, especially the fishermen. This ritual in the form of a tradition will usually involve various groups so that it will create an order of mutual help. In the process of Kenduri Laot, a prayer will usually be held together as a form of gratitude to the Creator. Apart from praying, the community also provides a banquet that functions to be eaten together and some of it is delivered by fishermen to the ocean which aims to be eaten by marine life, especially for fish. For the community, tradition is a tradition that aims to maintain culture, religion, cooperation, high solidarity, care for nature, care for social, responsibility, and others.

The culture of Kenduri Laot has never been taught in schools. Even though history subjects themselves have the opportunity to add teaching materials based on local wisdom. However, so far the teachers themselves still do not understand the meaning contained in the Kenduri Laot tradition. This also makes students have minimal knowledge of traditions. Whereas material based on local wisdom is very supportive of cultural preservation and inculcation of character values.

Based on the results of teachers ad students need analysis for learning media based on Kenduri Laot tradition, it was found that teachers and students considered it important to know the Kenduri Laot tradition. Considering that students in class XI come from various regions in Aceh with different ethnicities and cultures, it is very appropriate that Kenduri Laot tradition be developed into a learning medium with the aim of improving students' character values.

\section{The Use of Learning Media at SMA Plus Athiyah Banda Aceh City}

Based on the observations results conducted by the researchers on the use of historical learning media at SMA Plus Athiyah for two months, an overview is obtained, namely (1) the learning process in the classroom that has been going on so far both before the Covid-19 pandemic and during the Covid-19 pandemic period, generally, has used the learning media. So far, teachers have used various media, including Microsoft office powerpoints, pictures, concept maps, maps, 
audio, visual, and even audio-visual media. However, the teacher admited, not all material has been integrated into a media, but partly by integrating it with the learning model; (2) learning media developed by teachers could not be separated from the condition of adequate and professional Human Resources. Teachers' knowledge of the importance of a medium in learning forced the teachers to continue to be creative and continue to be encouraged by stakeholders such as school principals; (3) related to the condition of professional human resources also could not be separated from adequate school facilities. This could be seen from the state of the school facilities which could be said to be sufficient. The school has provided a computer laboratory that could be used by teachers and each class has been provided an LCD and infocus unit; and (4) three teachers of history subjects have a bachelor's degree in historical education and one of them has a master's degree. No wonder the mastery of learning materials and media was pretty good.

This picture was also strengthened by the results of interviews conducted with students, where during the learning process teachers often used learning media. The media used were various, such as documentary films, youtube, maps, pictures, and so on. Teachers who teach were historical education graduates from both Aceh and outside Aceh. Apart from computer laboratories for students, the school also had computer laboratories for teachers. In addition, in the learning process, teachers who use media would usually use LCD and infocus unit.

\section{Character Values Instilling based on Local Culture in SMA Plus Athiyah Banda Aceh}

The local culture-based learning model is an effort to support character education. According to Sariyatun (2013: 239) the benefit of culture-based learning is to develop students' appreciation, character, and national identity. In addition, it is also useful as an effort to develop a national sense of cultural identity so that students are motivated to protect their cultural heritage.

Local culture is usually inseparable from the life of the local community and has become a daily habit. Local culture contains values that are full of wisdom. Based on Maulani (2015: 54), local culture is the local cultural values of the people of an area that are formed naturally which are also obtained through a learning process from time to time. Local culture can be in the form of arts, traditions, thought, or customary law. In addition, local culture cannot be separated from the everyday life of students who are already familiar.

Based on the results of observations and interviews conducted with teachers and students on the culture-based character values instilling, so far, it was still lack of general picture. The teacher has only emphasized the instilling of character values based on material adapted to the material and lesson plans that refer to the 2013 curriculum. Meanwhile, it was still lack of the character values instilling based on local and national culture. Whereas according to Panjaitan et al., (2014: 5), culture-based lessons aim to find out the main essence of our culture (local and national) or traditional which basically has values (education and teaching). So that from these essential discoveries, we get teaching that is in accordance with our personality and character, namely Indonesia.

266 BRILIANT: Jurnal Riset dan Konseptual

Volume 6 Number 2, May 2021 
The Needs of Teachers and Students for Learning Media based on the Kenduri Laot Tradition for Increasing Character Values

Judging from the findings related to the conditions of the learning media usage and the local culture-based character values instilling used and applied at SMA Plus Athiyah, the development of culture-based learning media is deemed very necessary. This is known from the collection of sources related to the lack of understanding of teachers and students towards local culture, one of which is the Kenduri Laot tradition.

Based on the results of observations and interviews, it showed that teachers generally knew that the Kenduri Laot tradition is one of the traditions originating from the coastal communities of Aceh. According to the teachers, this tradition is an annual tradition that is usually carried out together. However, the procession and its value are still unknown. It was known only in general, namely the values of mutual cooperation. Likewise, with students, where some students even claim to have only heard the tradition without never saw it. A small proportion, especially those who lived in coastal areas, only know that because this tradition was an annual tradition, the process was less known. Regarding the values contained in Kenduri Laot tradition, students generally still did not know.

After conducting the discussion, then the questionnaire was distributed to the teachers and students. This questionnaire was a questionnaire that contained questions about how much teachers and students needed learning media based on Kenduri Laot tradition to increase students' character. Based on the results of the questionnaire distribution with 32 respondents, it was found that $87 \%$ agreed and needed learning media based on Kenduri Laot tradition for increasing character values. Thus, it can be said that teachers and students needed the learning media.

\section{A. The Development of Historical Learning Media based on Kenduri Laot Tradition: The Design of Historical Learning Media Development based on Kenduri Laot Tradition and Character Values}

Learning media for character values based on the Kenduri Laot tradition provide benefits as an effort to introduce culture to students. In this case, prior to the preparation of the initial media draft, it is necessary to formulate a media development concept map. The concept map can be seen in the following figure. 


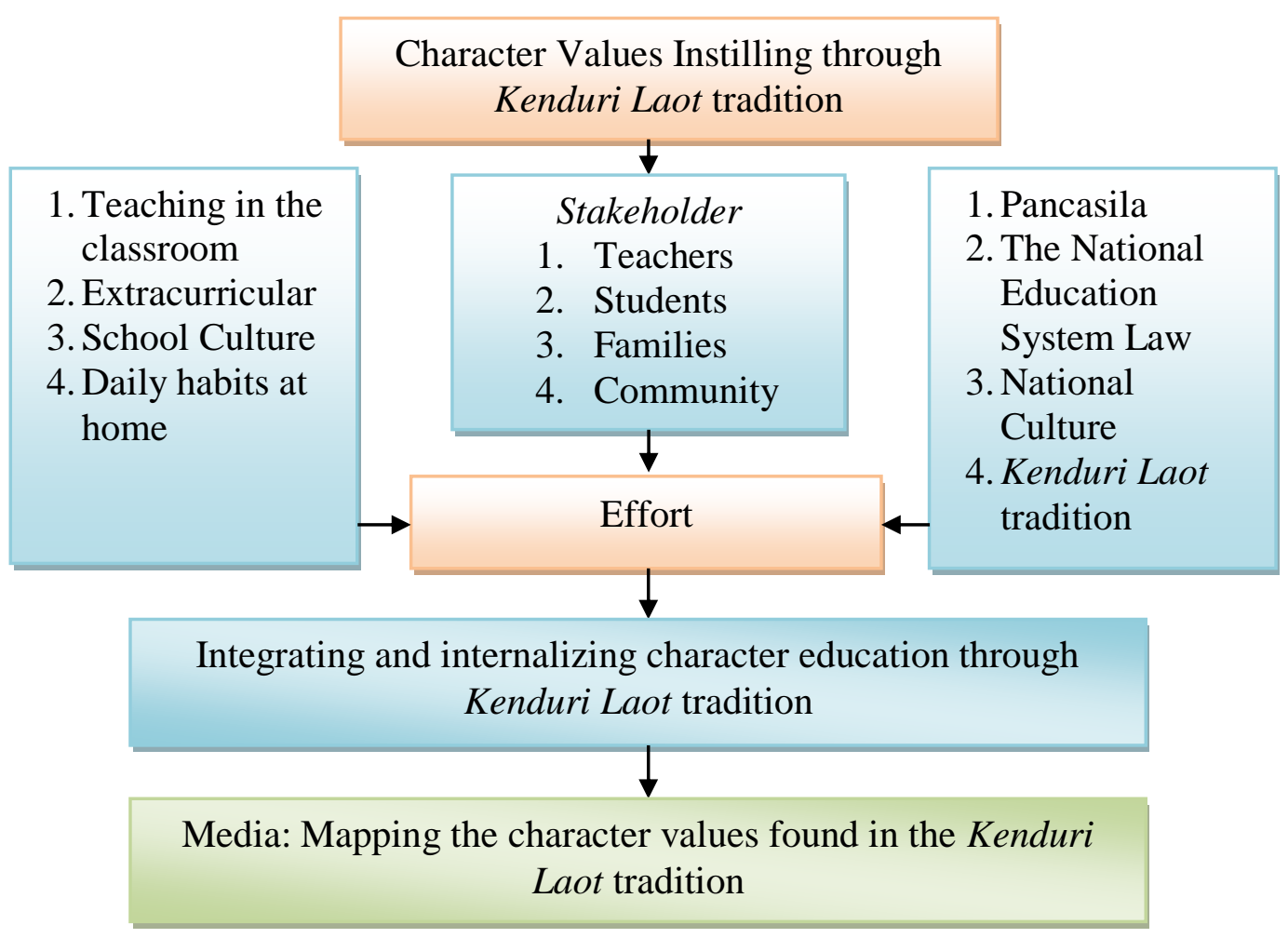

Figure 1. The Concept Map of Development

The concept map illustrates that the character education instilling based on the Kenduri Laot tradition must be supported by various stakeholders such as teachers, students, families, and the community. It can be done by teaching in class directly, extracurricular activities, school culture, and habituation. The character education instilling can be developed through learning media.

\section{The Analysis of Character Values in the Kenduri Laot Tradition}

Religion and culture are two things that often interact and also influence each other. Religion can influence culture in its formation and culture can influence the value system and religious symbols (Danrakati, 2019: 4). The same is the case with the Acehnese both who live in remote areas and coastal areas. Nurdin (2013: 139) states that culture and Islamic teachings have interacted and assimilated harmoniously in Acehnese community, all of this has happened since hundreds of years ago. The concrete forms of interaction and assimilation are applied in various fields.

One of the results of interaction and assimilation that is still developing today is the Kenduri Laot tradition. In Acehnese community the tradition of Kenduri Laot is also often referred to as Khanduri Maulod. This tradition itself is believed to be a form of interaction and assimilation of Islam with local culture. According to Syarif (2003: 24), Kenduri Laot is an effort to unite awak laot (sailors) and strengthen the customs. Through this tradition, panglima laot, para pawing, mugee, and fishermen can strengthen their ties and also become an opportunity to renew their customs and confirm to the general public that these customs still exist and apply. 
This annual ritual has been carried out from generation to generation. This tradition cannot be separated from the life of fishermen, which means by the coastal community of Aceh (Manan, 2016: 468). Kenduri Laot is a traditional ceremony that aims to strengthen the existence of customary law and its institution, namely Panglima Laot. According to several sources, if kenduri is carried out before the eastern season, it means kenduri as a form of community gratitude to Allah SWT. This kenduri is also closely related to preserving the environment, maintaining human relations with nature, growing together, maintaining human relations with God, maintaining human relations, abstinence from going to sea, and containing spiritual power. Based on the results of the source analysis, it is found that the character values contained in the Kenduri Laot tradition are as follows: (1) religious; (2) tolerance; (3) creative; (4) democratic; (5) spirit of nationality; (6) rewarding achievement; (7) friendly; (8) peace-loving; (9) environment care; (10) social care; and (11) responsibility. The media that will be developed contain these character values. Where each picture will be accompanied by a synopsis that introduces the students that these values are contained in Kenduri Laot tradition.

\section{Expert Validation Test}

In accordance with the stages of research activities, product improvement is an important step in research and development. In order to determine the deficiencies of the media that had been designed, an expert validation test was carried out by three experts. The validation experts were lecturers at the Faculty of Teacher Training and Education at Universitas Syiah Kuala, each of whom is a master of the media field.

Based on the results of the material expert validation test questionnaire obtained an average result of 5 . Thus, the material presented was in the very good category. The results of the media expert validation questionnaire with an assessment of several aspects got an average value of 5. Thus, the media that had been compiled was included in the very good category. As for the results of the graphical expert validation questionnaire, the average value was 5 . Thus, it can be said that the media can be used for further testing.

\section{Small and Large Group One-on-One Trials}

This stage is the stage where the media will be tested one by one or called a small group. This trial aims to obtain data to determine the feasibility of the media to be used in learning. Small group trials were carried out in the same school with 5 students as respondents. This test used a questionnaire with a rating scale ranging from 1 to 5 . The results of the one-on-one trial of small group scores can be seen in the following line. 


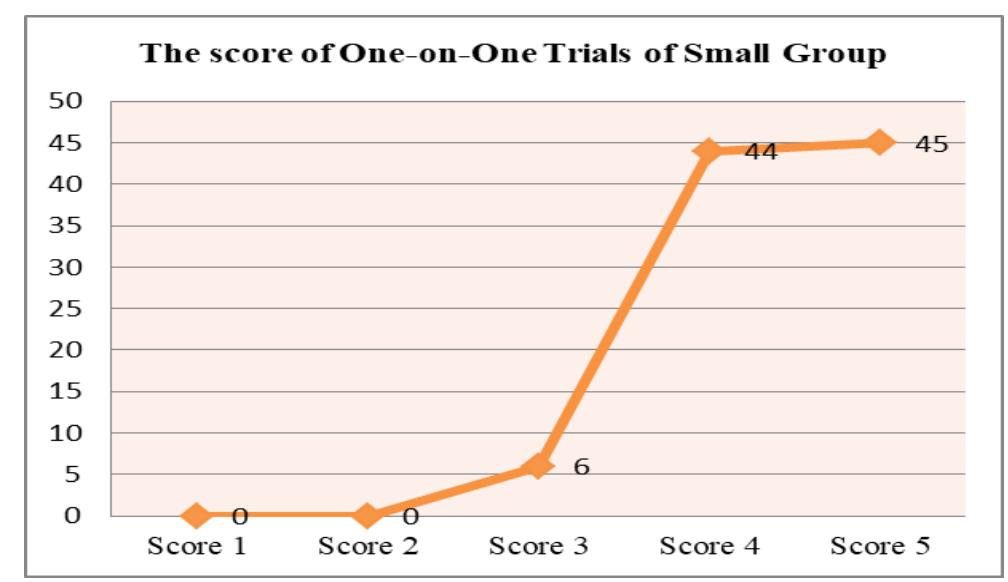

Figure 2. The score of One-on-One Trials of Small Group

Based on the line above, it shows that the scores on a scale of 1-5 in this one-on-one trial of small group, from the five students gave different scores. A score of 1 "very poor" gets a value of 0 , for a score of 2 "poor" gets a value of 0 , for a score of 3 "fair" gets a score of 2 , for a score of 4 "good" gets a value of 11 , and for a score of 5 "very good" gets a value 9. The average number of these trials was 4.4 with a total of 95 in the "very good" category.

Because the media was deemed appropriate, then One-on-One trials of large group was carried out. This test was also carried out in the same school with 13 students as the respondents with different levels of ability. The results of the one-on-one trials of large group can be seen in the following line.

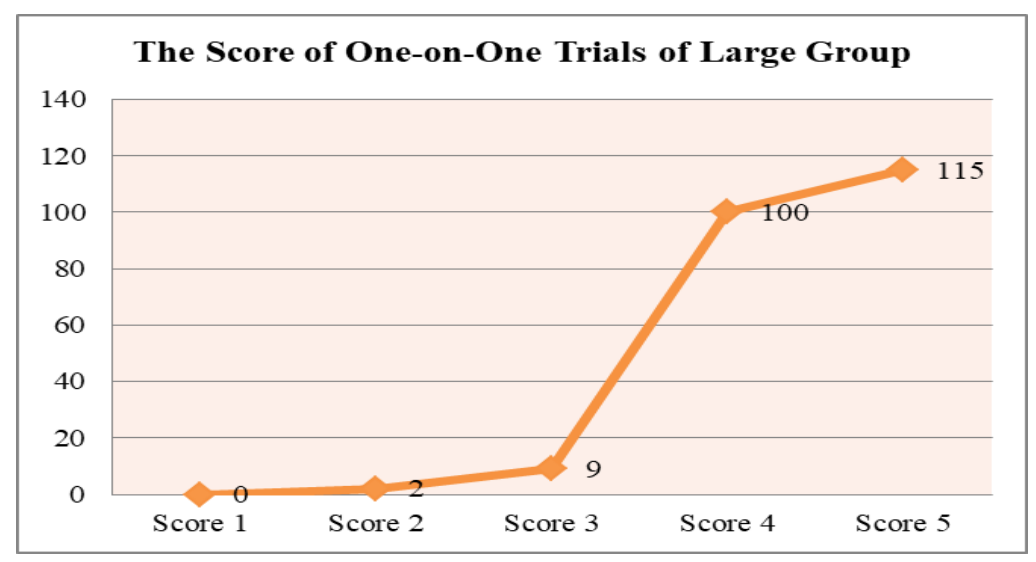

Figure 3. The Score of One-on-One Trials of Large Group

Based on the line above, it shows that the scores on a scale of 1-5 in this oneon-one trial of large group, from the thirteen students gave different scores. A score of 1 "very poor" gets a value of 0 , for a score of 2 "poor" gets a value of 1 , for a score of 3 "fair" gets a value of 3 , for a score of 4 "good" gets a value of 25 , and for a score of 5 "very good" gets a value 23 . The average number of these trials was 4.5 with a total of 227 and was in the "very good" category.

Based on the results of these trials, there were several notes from students that the volume was not loud enough and the sound was sometimes unclear. Because of these suggestions, then it was conducted the consultation with experts for improvement with a note of minor improvements. 


\section{B. Media Effectiveness Test \\ Equivalence Pre-Test of Character Values of Control Group and Experiment Group}

In the early stages of testing the effectiveness of learning media in the control group and the experimental group, it must first be tested for the level of character attitudes that students have. This test was carried out in the form of a character questionnaire pre- test to determine the level of the initial character of students. The results of the pre-test are shown in table 1 below.

Table 1. Students' Character Values Pre-Test (Equivalence Test)

\begin{tabular}{cccccc}
\hline & Control Group & \multicolumn{3}{c}{ Experimental Group } \\
\hline Number of & Total Score & Average & Number of & Total Score & Average \\
Students & & Score & students & & Score \\
30 & 3342 & 132 & 30 & 3335 & 129 \\
\hline
\end{tabular}

Based on the results of the equivalence trial presented in the table above, it shows that the character values pre-test between the control group and the experimental group have the equivalent value. After the equivalence test, the normality test was carried out before testing the character values by calculating the SPSS using the One-Sample Kolmogorov-Smirnov-Test. The results of the One-Sample Kolmogorov-Smirnov-Test are shown in table 2 below.

Table 2. Students' Character Value Pre-Test (Normality Test)

\begin{tabular}{lcccc}
\hline Group & Degree of Free & $\begin{array}{c}\text { Kolmogorov } \\
\text { Smirnov }\end{array}$ & Sig. (2-tailed) & Conclusion \\
\hline Control & 30 & 1.227 & 0.103 & Normal \\
Experimental & 30 & 1.199 & 0.180 & Normal \\
\hline
\end{tabular}

Based on the results of the trials that have been presented in table 2 above, it can be stated that the significance value is $>0.05$. Thus, it can be said that the values are normally distributed, with the comparison level of significance values in the control group amounting to $0.103>0.05$ and in the experimental group amounting to $0.180>0.05$. Thus, it can be concluded that the values of the two groups are normally distributed.

The next stage is to conduct a homogeneity pre-test of character values. The test also used SPSS calculations using Oneway Anova. The results of the homogeneity test are shown in Table 3 below.

Table 3. Students' Character Value Pre-Test (Homogeneity Test)

\begin{tabular}{|c|c|c|c|c|c|}
\hline \multicolumn{5}{|c|}{ Test of Varian Homogeneity } & Anova \\
\hline Levene & df1 & df2 & Sig. & $\mathrm{F}$ & Sig. \\
\hline Statistic & 1 & 66 & 0.379 & 8.908 & 0.005 \\
\hline
\end{tabular}

A data is said to be homogeneous if the significance value is $>0.05$. Based on table 3 above shows that the significance result of the homogeneity test is 0.379 which means $>0.05$. Thus, it can be concluded that the character values pre-test in the two groups are homogeneous. After the data is declared to be normally distributed and homogeneous, then the t-test is carried out. This test 
itself used the Independent-Sample-Test calculation. The test results will be presented in table 4 below.

Table 4. Students' Character Value Pre Test (t-test)

\begin{tabular}{l|cccc}
\hline Pair & $\mathbf{t}$ & $\mathbf{N}$ & df & Sig. (2-tailed) \\
\cline { 2 - 5 } $\begin{array}{l}\text { Control } \\
\text { Experimental }\end{array}$ & -2.877 & 30 & 49 & 0.244 \\
\hline
\end{tabular}

Based on the results of the t-test calculations that have been presented in table 4 above, it is known that the significance value (Sig. (2-tailed) is 0.244. Because the significance value is $0.244>0.05$, the decision to test based on the hypothesis is $\mathrm{H} 0$ rejected and it can be concluded that the two groups have the same ability of character values.

\section{The Test Results of the Character Values of the Experimental Group}

In this section, it was conducted the test of improving character values of each group. The test was carried out by comparing the pre-test and the post-test score of each group. The purpose of this test was to test the relationship of the effect of a significant positive increase in the experimental group before and after given treatment. The hypothesis are as follows:

$\mathrm{H}_{0} \quad$ : There was no positive and significant increase in the character values of students before and after given learning media.

$\mathrm{H}_{1} \quad$ : There was a positive and significant increase in the character values of students before and after given learning media.

The following will present a comparison of the scores between the pretest and posttest of the character values of the experimental group students. The results will be presented in table 5 below.

Table 5. Pre-Test and Post Test Score of the Character Values of Experimental

\section{Group}

\begin{tabular}{cccccc}
\hline \multicolumn{2}{c}{ The Pre-test Score of the Character } & \multicolumn{3}{c}{ The Post-test Score of the Character } \\
Values & & \multicolumn{3}{c}{ Values } \\
\hline $\begin{array}{c}\text { Number } \\
\text { of }\end{array}$ & Total Score & Average & $\begin{array}{c}\text { Number of } \\
\text { Students }\end{array}$ & Total Score & Average \\
& & & &
\end{tabular}

Students

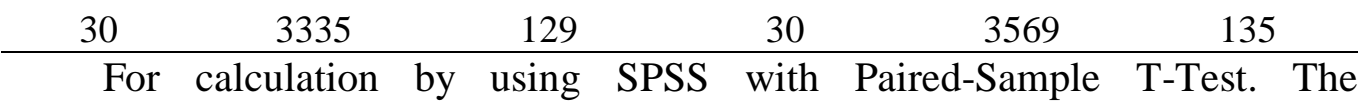
requirements that must be met in performing t-test on non-parametric statistical data were normally distributed and homogeneous. Therefore, the normality and homogeneity test must be carried out. The normality test itself used the OneSample-Kolmogorov-Smirnov Test. The test results can be seen in table 6 below.

Table 6. The Normality Test of Pre-Test and Post-Test of Character Values of Experimental Group

\begin{tabular}{lcccc}
\hline Category & $\begin{array}{c}\text { Degree of } \\
\text { Free }\end{array}$ & $\begin{array}{c}\text { Kolmogorov } \\
\text { Smirnov }\end{array}$ & Sig. (2-tailed) & Conclusion \\
\hline Pre-test & 30 & 0.799 & 0.539 & Normal \\
Post-test & 30 & 0.658 & 0.841 & Normal \\
\hline
\end{tabular}


Based on the results of the statistical calculation test, it states that the significance $>0.05$, the data can be said to be normally distributed. As it is known that the pre-test results are $0.539>0.05$ and the post-test results are $0.841>0.05$, both results are significant. Thus, it can be concluded that the pre-test and posttest data score for students' character values are normally distributed. Furthermore, because the data is nomally distributed, it is followed by a homogeneity test. The test was carried out in order to fulfill the second requirement before carrying out the t-test. The results of calculations using Oneway-Anova can be seen in table 7 below.

Table 7. Homogeneity Test of Pre-Test dan Post-Test of Character Value of Experimental Group

\begin{tabular}{cccc|cc}
\hline \multicolumn{2}{c|}{ Test of Homogeneity of Variances } & \multicolumn{3}{c}{ Anova } \\
\hline Levene Statistic & df1 & df2 & Sig. & F & Sig. \\
0.109 & 1 & 49 & 0.801 & 8.705 & 0.003 \\
\hline
\end{tabular}

The data requirements are said to be homogeneous if the significance value is $>0.05$. After the homogeneity test was carried out using Oneway-Anova, the significance value was 0.801 . Because the significance value is $0.801>0.05$, it can be concluded that the pre-test and post-test values are homogeneous. After, the data is declared to be normally distributed and homogeneous, the t-test was conducted. This test used the Paired-Sample Test. The results of the calculation output can be seen in table 8 below.

Table 8. t-test of Pre-Test and Post-Test of Character Values of Experimental

\begin{tabular}{c|c|c|c|c}
\multicolumn{5}{c}{ Group } \\
\hline Pair 1 Pre-Test & $\mathbf{N}$ & $\mathbf{t}$ & Df & Sig. (2-tailed) \\
\cline { 2 - 6 } Post-Test & 30 & -4.673 & 25 & 0.000 \\
\hline
\end{tabular}

The requirement of this test is if the significance value $<0.05$ then $\mathrm{HO}$ is rejected. Based on table 8 above, it is known that $0.000<0.05$, thus $\mathrm{H} 0$ is rejected. Thus it can be concluded that there is a positive and significant increase in the character values of students before and after given learning media (H1).

\section{The Test Results for Increasing the Character Values of Control Group}

In this section, the results of the increasing of students' character values in the control group will be presented. In this group no special treatment was given, but only using PPT media. Meanwhile, for the self-test there was no difference with the previous test in the experimental group. The following will be presented the comparison of the scores between the pre test and the post test of the character values of the control group students. The results will be presented in table 9 below.

Table 9. The Score of Pre-Test and Post-Test of Character Values of Control Group

\begin{tabular}{|c|c|c|c|c|c|}
\hline \multicolumn{3}{|c|}{$\begin{array}{l}\text { The Pre-test Score of the Character } \\
\text { Values }\end{array}$} & \multicolumn{3}{|c|}{$\begin{array}{c}\text { The Post-test Score of the Character } \\
\text { Values }\end{array}$} \\
\hline $\begin{array}{c}\text { Number of } \\
\text { Students }\end{array}$ & Total Score & Average & $\begin{array}{c}\text { Number of } \\
\text { Students }\end{array}$ & Total Score & Average \\
\hline 30 & 3342 & 132 & 30 & 3411 & 133 \\
\hline
\end{tabular}

The requirements that must be met in conducting the t-test in statistical data non parametriks is when the data is normally distributed and homogeneous. 
Therefore, the next to do normality test and homogeneity. Normality test yourself using One-Sample-Ko lmogorov-Smirnov Test. The test results can be seen in table 10 below.

Table 10. The Normality Test of Pre-Test and Post-Test of Character Values of Control Group

\begin{tabular}{lcccc}
\hline Category & $\begin{array}{c}\text { Degree of } \\
\text { Free }\end{array}$ & $\begin{array}{c}\text { Kolmogorov } \\
\text { Smirnov }\end{array}$ & Sig. (2-tailed) & Conclusion \\
\hline Pre-Test & 30 & 0.662 & 0.491 & Normal \\
Post-Test & 30 & 0.507 & 0.613 & Normal \\
\hline
\end{tabular}

Based on the results of the statistical calculation test, it states that the significance $>0.05$, the data can be said to be normally distributed. As it is known that the pre-test results are $0.539>0.05$ and the post test results are $0.613>0.05$, both results are significant. Thus it can be concluded that the pre-test and post-test score for the students' character values in the control group are normally distributed. Since the data is normally distributed, it is followed by a homogeneity test. This test is conducted to meet the second requirement before performing the t-test. The results of calculations using Oneway-Anova can be seen in table 11 below.

Table 11. The Homogeneity Test of Pre-Test and Post-Test of Character Values of Control Group

\begin{tabular}{cccc|cc}
\hline \multicolumn{2}{c|}{ Test of Homogeneity of Variances } & \multicolumn{3}{c}{ Anova } \\
\hline Levene Statistic & df1 & df2 & Sig. & F & Sig. \\
0.106 & 1 & 47 & 0.721 & 8.703 & 0.003 \\
\hline
\end{tabular}

The data requirements are said to be homogeneous if the significance value is $>0.05$. After the homogeneity test was carried out using Oneway-Anova, the significance value was 0.801 . Because the significance value is $0.721>0.05$, it can be concluded that the pre-test and post-test scores are homogeneous. After the data is declared to be normally distributed and homogeneous, the next test is the ttest. This test used the Paired-Sample Test. The results of the calculation output can be seen in table 12 below.

Table 12. The t-test of Pre-Test and Post-Test of Character Values of Control Group

\begin{tabular}{c|c|c|c|c}
\hline Pair 1Pre-Test & $\mathbf{N}$ & $\mathbf{t}$ & df & Sig. (2-tailed) \\
\cline { 2 - 5 } Post-Test & 30 & -3.891 & 25 & 0.024 \\
\hline
\end{tabular}

The requirements of this test are if the significance value $<0.05$ then $\mathrm{H} 0$ is rejected and if the significance value is $>0.05$ then $\mathrm{HO}$ is accepted. Based on the table above, it is known that $0.024>0.05$, thus H0 is accepted. So it can be concluded that $\mathrm{H} 0$ there is no positive and significant increase in the character values of students before and after given PPT.

Based on the test results from the two groups, it can be said that in the experimental group there was a positive and significant increase in the character values of students before and after being given audio-visual media based on the Kenduri Laot tradition. Meanwhile, the control group showed no positive and significant increase in the character values of students before and after being given the PPT of Kenduri Laot tradition. 


\section{CONCLUSION}

Based on the results of exploration at SMA Plus Athiyah, it showed that the use of learning media had been very good so far. Teachers had used media in various forms. This was also supported by adequate school facilities. However, another problem was found related to character instilling, especially through local culture. So far, the teacher had never developed local culture-based material such as the Kenduri Laot tradition, which required character values. Based on the results of the analysis of the distribution of the questionnaire, it was found that teachers and students really need learning media based on the Kenduri Laot tradition to increase the students' character values.

The development of audio-visual learning media based on the Kenduri Laot tradition to increase character is carried out based on the needs of teachers and students. In addition, the media being developed is inseparable from several stages starting from the analysis of media development, analysis of the values contained in the Kenduri Laot tradition, testing designs to experts, limited trials consisting of small groups and large groups. All of these stages correspond to the development stages of Borg and Gall. At this stage, it can be concluded that the media developed is good enough even though there are slight improvements.

The final stage is an effectiveness test which carried out widely. This test was carried out in two large groups, namely the control group and the experimental group. Based on the test results from the two groups, it can be said that in the experimental group, there was a positive and significant increase in the character values of students before and after given audio-visual media based on Kenduri Laot tradition. Meanwhile, the control group showed no positive and significant increase in the students character values before and after given the PPT of Kenduri Laot tradition.

\section{SUGGESTION}

From the results of this study, it can be said that the learning media based on Kenduri Laot tradition can increase students' character values. With this research, it is hoped that teachers can continue to make breakthroughs and new innovations for the advancement of our education

\section{REFERENCES}

Apriana, E. (2016). Kearifan Lokal Masyarakat Aceh dalam Konservasi Laut. Serambi Saintia, IV(1), 57-66.

Azis, A., Haikal, M., \& Iswanto, S. (2018). Internalisasi Nilai-Nilai Budaya Toleransi dalam Pembelajaran Sejarah (Studi Kasus SMA Negeri 1 Banda Aceh). Briliant: Jurnal Riset Dan Konseptual, 3(3), 287-299.

Danrakati. (2019). Mengenal Ritual Kenduri Laut Masyarakat Pesisir Aceh. In Artikel Tugas WSBM 24.

Dinangsit, D. (2014). Manajemen Terpadu Pengelolaan Perilaku dalam Konteks Pendidikan Jasmani di Sekolah. In N. Hanifah (Ed.), Seminar Nasional Pendidikan Dasar "Membedah Anatomi Kurikulum 2013 untuk Membangun Masa Depan Pendidikan yang Lebih Baik” (pp. 530-538). UPI Sumedang Press.

Ferdianto, F., \& Setiyani. (2018). Pengembangan Bahan Ajar Media Pembelajaran Berbasis Kearifan Lokal Mahasiswa Pendidikan Matematika. JNPM (Jurnal 
Nasional Pendidikan Matematika), 2(1), 37-47.

Fuad, I. (2005). Dasar-Dasar Kependidikan. Asdi Mahasatya.

Gall, M. D., Gall, J. P., \& Borg, W. R. (2003). Educational research: An introduction (7th ed.). In Boston, MA: A \& B Publications.

Ingsih, K., Ratnawati, J., Nuryanto, I., \& Astuti, S. D. (2018). Pendidikan Karakter: Alat Peraga Edukatif Media Interaktif. Penerbit Deepublish.

Joenaidy, A. M. (2018). Guru Asyik, Murid Fantastik! (M. Romadhony (ed.); Pertama). DIVA Press.

Kurniasari, N., \& Nurlaili. (2012). Fungsi Laut dalam Menjaga Harmonisasi Hidup Masyarakat Adat Lambadalhok, Aceh Besar. Buletin Riset Sosek Kelautan Dan Perikanan, 7(2), 41-45.

Manan, A. (2016). The Ritual of Khanduri Laot in Lowland Aceh: An Ethnographic Study in South, South West and West Aceh. MIQOT, XL(2), 468-483.

Maulani, A. (2015). Pengembangan Media Film Dokumenter dalam Pembelajaran IPS Berbasis Konstruktif-Kolaboratif untuk Meningkatkan Pemahaman Siswa terhadap Budaya Lokal di SMK Negeri 3 Kudus. Universitas Sebelas Maret.

Mustari, M. (2014). Nilai Karakter Refleksi untuk Pendidikan. PT RajaGrafindo Persada.

Nurdin, A. (2013). Revitalisasi Kearifan Lokal Aceh: Peran Budaya dalam Menyelesaikan Konflik Masyarakat. Jurnal Analisis: Jurnal Studi Keislaman, XIII(1), 135-154.

Panjaitan, A. P., Darmawan, A., Maharani, Purba, I. R., Rachmad, Y., \& Simajuntak, R. (2014). Korelasi Kebudayaan \& Pendidikan: Membangun Pendidikan Berbasis Budaya Lokal (I). Yayasan Pustaka Obor Indonesia.

Putra, N. (2013). Research \& Development: Penelitian Pengembangan Suatu Pengantar (1st ed.). PT RajaGrafindo Persada.

Samani, M., \& Hariyanto. (2011). Konsep dan Model Pendidikan Karakter. Rosda.

Sariyatun. (2013). Pengembangan Model Pendidikan Nilai-Nilai Budaya di SMP Berbasis Tradisi Seni Batik Klasik Surakarta. Paramita: Jurnal Sejarah Dan Pembelajaran Sejarah, 23(2), 230-241.

Siswoyo, D. (2014). Ilmu Pendidikan. UNY Press.

Suryana, N., Fajri, H., \& Iswanto, S. (2020). Pengembangan Media Pembelajaran IPS Sejarah Berbasis Situs-Situs Tsunami Untuk Meningkatkan Kesadaran Sejarah Siswa SMP Negeri Kabupaten Pidie. Jurnal Agastya, 10(1), 106127.

Syarif, S. M. (2003). Riwang U La'ot: Leuen Pukat dan Panglima La'ot dalam Kehidupan Nelayan di Aceh (L. Munir (ed.)). Yayasan Rumpun Bambu dan CSSP.

Yusuf, A. M. (2017). Metode Penelitian Kuantitatif, Kualitatif \& Penelitian Gabungan (4th ed.). Kencana.

Zuriah, N., Syaifuddin, M., \& Taufik, M. (2017). Pendidikan APCI Model Pendidikan Karakter Bangsa untuk Kemandirian Pangan Melalui Gerakan Aku Cinta Produk Indonesia. Surya Pena Gemilang. 